\title{
Potentiometric Membrane Sensors for Levamisole Determination
}

\author{
Natalia Zubenya ${ }^{1}$, Zholt Kormosh ${ }^{1, *}$, Diana Saribekova ${ }^{2}$ and Sergei Sukharev ${ }^{3}$ \\ ${ }^{1}$ Eastern European National University, Voli av., 13, 43025 Lutsk, Ukraine \\ ${ }^{2}$ Kherson National Technical University, Beryslavske av., 24, 73008 Kherson, Ukraine \\ ${ }^{3}$ State High Educational Establishment «Uzhgorod National University», Pidgirna str., 46, 88000 Uzhgorod, \\ Ukraine
}

\begin{abstract}
The ion pair (IP) of levamisole with $\mathrm{BiI}_{4}{ }^{-}\left(\mathrm{SbI}_{4}{ }^{-}\right)$for the levamisole-selective sensor with a PVC membrane containing - ions were developed. Thermal behavior of obtained IP was investigated by differential thermal analysis that would show the thermal stability and the character of the decomposition of the complex. The thermolysis of $\mathrm{Lev}^{+} \mathrm{BiI}_{4}{ }^{-} \mathrm{IP}$ undergoes three stages that fit a theoretical interpretation. The linearity ranges of levamisole sensors function are $7.9 \times 10^{-6}-1 \times 10^{-1}\left(7.9 \times 10^{-5}-1 \times 10^{-1}\right)$ M. The Nernstian slope of $50.6-53.4 \mathrm{mV} \mathrm{pC}^{-1}$ and detection limit of $5.0 \times 10^{-5}-1.5 \times 10^{-4}$ ) M. The working range of $\mathrm{pH}$ is $2.8-6.0$. The efficiency of the use of electrodes for levamisole content control in pharmaceutical preparations was shown by direct potentiometry and potentiometric titration methods.
\end{abstract}

Key words: Levamisole; Tetraiodobismutate; Tetraiodostibiate; Ion Pair; Potentiometry.

\section{Introduction}

Levamisole (Lev), (S)-6-Phenyl-2,3,5,6tetrahydroimidazo[2,1-b]thiazole (Fig. 1) is a potent broad-spectrum antihelmintic drug, which is widely used in veterinary medicine for the control of gastrointestinal parasites in cattle, sheep and pigs. It is normally administered orally, by pour-on or by subcutaneous or intramuscular injection. The recommended dose is $8 \mathrm{mg} / \mathrm{kg}$ body weight. It has been used as an immunostimulant in humans. Levamisole hydrochloride is used in the treatment of a variety of immune diseases and autoimmune diseases. Levamisole hydrochloride liniments have been developed for the administration of this drug, which can treat skin type immune therapy effectively. Lev - white to off-white crystalline powder (light yellow crystalline powder), soluble in water, methanol, slightly soluble in ethanol, very slightly soluble in chloroform, insoluble in acetone; stable under ordinary conditions ${ }^{1}$.

A great deal of work has been done by the scientists about the current application and future possibilities for altering the drug activities and evaluation with new method development by instrumental methods.<smiles>c1ccc(C2CN3CCSC3=N2)cc1</smiles>

Fig. 1. The chemical structure of Levamisole.

Various techniques have been used for the determination of levamisole in biological fluids. They include gas chromatography with nitrogenphosphorus detection (GC-NPD) ${ }^{2}$ and flame ionization (GC-FID) [3] and liquid chromatography (LC) with ultraviolet (UV) detection ${ }^{4-7}$. Several methods have been developed for levamisole quantification such as polarography ${ }^{8}$, by a

*Corresponding author: Zholt Kormosh

Email address: kormosh@eenu.edu.ua; zholt-1971@yandex.ua DOI: http://dx.doi.org/10.13171/mjc61/016111516/kormosh turbidimetric method and flow-injection analysis ${ }^{9}$. Were used as potentiometric methods ${ }^{10,11}$

Potentiometric determination based on ionselective electrodes (ISEs) offers several advantages such as speed and ease of preparation and procedures, simple instrumentation, relatively fast response, wide dynamic range, reasonable selectivity and low cost ${ }^{10-19}$. The present work establishes a new simple, accurate, rapid and reproducible Received August 9 ${ }^{\text {th }}, 2016$ Accepted September 14 $4^{\text {st }}, 2016$ Published November $15^{\text {th }}, 2016$ 
technique for determination of levamisole, by construction and electrochemical evaluation of novel potentiometric sensors. The sensors incorporate the ion-pair (IP) complex of levamisole cation with $\mathrm{SbI}_{4}{ }^{-}$ , $\mathrm{BiI}_{4}^{-}$as counter anions in plasticized polyvinyl chloride (PVC) matrix. Due to the functional properties of IP to donate both a cation and an anion as potential-determining ions, they are universal ionophores [18]. It is likely that solubility is the main restriction for their use as ionophores. The solubility of IPs should be sufficiently low in aqueous phase; otherwise they will be washed out from the membranes, and at the same time, high in the membrane phase; otherwise, it will be difficult to obtain a homogeneous membrane. Previously, we analyzed the applicability of ISEs based on ion-pair as electrode-active substances in analysis of pharmaceuticals ${ }^{12-19}$.

\section{Experimental Section}

\section{Chemicals and reagents}

All chemicals of analytical-reagent grade. Distilled water was used to prepare all solutions and in all experiments.

The modeling of the membrane composition of the ion-selective sensors utilized high molecular weight polyvinyl-chloride (PVC), dibutyl phthalate (DBP), dibutyl sebacate (DBS), diethyl phthalate (DEP), dioctyl phthalate (DOP), dinonyl phthalate (DNP), tricresyl phosphate (TCP), tetrahydrofurane (THF). They were obtained from Sigma-Aldrich.

Standard solutions and buffers were prepared freshly with deionized water. Buffer solutions were prepared by mixing corresponding amounts of 0.04 $\mathrm{M} \mathrm{H}_{3} \mathrm{BO}_{3}, 0.04 \mathrm{M} \mathrm{CH}_{3} \mathrm{COOH}, 0.04 \mathrm{M} \mathrm{H}_{3} \mathrm{PO}_{4}$ and $0.2 \mathrm{M} \mathrm{NaOH}$.

\section{Procedure}

The performance of the sensor was investigated by measuring the emf values of various Lev hydrochloride solutions.

An IA-123 model ionometer with $\mathrm{Ag} / \mathrm{AgCl}$ reference electrode was used for the measurements of potential difference at $(25.0 \pm 0.1){ }^{\circ} \mathrm{C}$.

Stock solution $(0.01 \mathrm{M})$ of levamisole was prepared as follows: accurately measured portion of the injection solution equivalent to $118 \mathrm{mg} / \mathrm{L}$ of the Lev, $5 \mathrm{ml}$ of buffer solution with $\mathrm{pH} 4.0$ and diluted to $50 \mathrm{~mL}$ with $0.1 \mathrm{M}$ solution of $\mathrm{LiCl}$. Further, it was diluted to produce working standards solutions with the concentration range $1 \times 10^{-1}-1 \times 10^{-7} \mathrm{M}$.

An ion-pair of levamisole $\mathrm{SbI}_{4}^{-}\left(\mathrm{BiI}_{4}^{-}\right)$was prepared by mixing equal quantities of $1 \times 10^{-2} \mathrm{M}$ Lev and anions $\mathrm{SbI}_{4}^{-}, \mathrm{BiI}_{4}^{-}$. The solution was settled for 2 $\mathrm{h}$ and the IP sediment was filtered (quantitative rapid filter paper). This residue was treated with $50 \mathrm{ml}$ of cold distilled water. The precipitate was dried as an electrode active substance for preparing the levamisole-sensitive sensor.

The description of the electrode construction and membrane phase preparation was presented in earlier papers ${ }^{12-19}$. The sensing membrane was prepared by mixing $70 \mathrm{mg}$ of PVC powder and $15 \mathrm{mg}$ of $\mathrm{Lev}^{+} \mathrm{SbI}_{4}{ }^{-}$or $\mathrm{Lev}^{+} \mathrm{BiI}_{4}{ }^{-}$with $0.12 \mathrm{~mL}$ of plasticizers. The mixture was stirred until the PVC was well moistened, and then the mixture was dispersed in 0.5 $\mathrm{mL}$ THF. The resulting mixture was transferred into a glass dish of $25 \mathrm{~mm}$ diameter. The solvent was evaporated slowly at a room temperature until a solid membrane with about $0.3 \mathrm{~mm}$ thickness was formed. A desired piece of the membrane was cut and then was attached to an end of polyethylene tube using viscous solution of PVC as an adhesive. The resulting sensor was then filled with an internal solution of $1 \times 10^{-2} \mathrm{M} \mathrm{Lev}^{+}$and conditioned for 15 min. Then, a copper wire was immersed into the tube.

The prepared electrode was conditioned by soaking in $1 \times 10^{-2} \mathrm{M} \mathrm{Lev}^{+}$solution for $2 \mathrm{~h}$.

Aliquots $(5 \mathrm{ml})$ of $1 \times 10^{-1}-1 \times 10^{-7} \mathrm{M}$ aqueous $\mathrm{Lev}^{+}$in $0.04 \mathrm{M}$ acetate buffer of $\mathrm{pH} 4.0$ were transferred into $50 \mathrm{ml}$ beakers. The $\mathrm{Lev}^{+} \mathrm{PVC}$ membrane sensor (indicator electrode) together with the single junction $\mathrm{Ag} / \mathrm{AgCl}$ reference electrode were immersed in the $\mathrm{Lev}^{+}$solution. The solution was stirred and the potential reading was recorded after stabilization to $\pm 0.3 \mathrm{mV}$. The electromotive force was plotted as a function of $\mathrm{pC}\left(\mathrm{Lev}^{+}\right)$. The calibration plot was used for measuring samples under the same conditions.

\section{Sample preparation}

\section{Tablets}

Five tablets were accurately weighted and finely powdered. A portion of powder equivalent to one tablet of $\mathrm{Lev}^{+}$was accurately weighted, transferred to $50 \mathrm{ml}$ volumetric flask, dissolved and shacked for 15 minutes with $5 \mathrm{ml}$ of $0.04 \mathrm{M}$ acetate buffer of $\mathrm{pH}$ 4.0 and $5 \mathrm{ml}$ of $0.1 \mathrm{M}$ solution $\mathrm{LiCl}$. The solution was then completed to the mark.

\section{Biological fluids (drugs in urine samples)}

Aliquots of $5 \mathrm{ml}$ urine were transferred to 100 $\mathrm{ml}$ measuring flasks, made up to the mark with the respective buffers (solution 1). Solution having concentration of $118 \mathrm{mg} / \mathrm{ml}$ levamisole was used. 1.0, $2.0 \mathrm{ml}$ aliquots of the drug solution were transferred into $50 \mathrm{ml}$ measuring flasks and made up to the mark with the solution 1 and were analyzed by potentiometric determination with the respective drug electrodes.

The emf of the solution was measured above and the corresponding concentration was determined using the calibration plot 


\section{Results and discussion}

\section{The thermal studies}

The thermal studies (TG, DTG and DTA) were carried out on an apparatus for complex dynamic thermal analysis under the following conditions: temperature range $20-700{ }^{\circ} \mathrm{C}$, heating rate $5 \mathrm{~K} / \mathrm{min}$, sample weight $27.3 \mathrm{mg}$, static nitrogen medium, channel sensitivities: DTA - $150 \mathrm{mV}, \mathrm{TG}-50 \mathrm{mV}$.

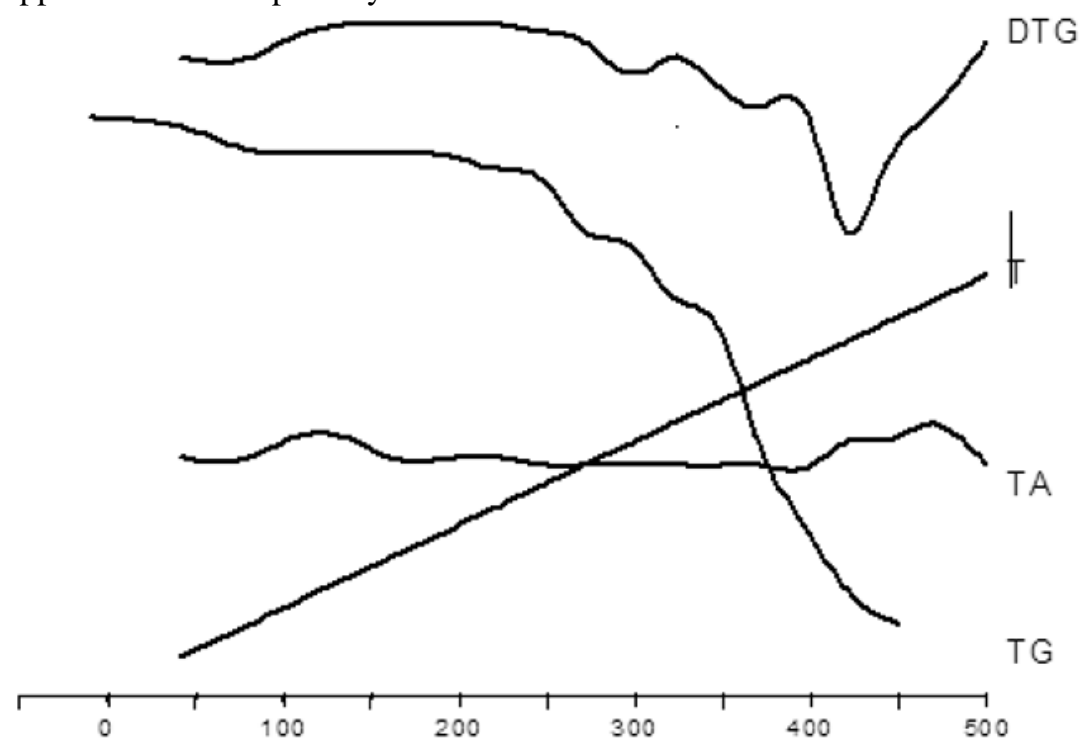

Figure 2. Simultaneous TG, DTA and DTG curves of the $\mathrm{Lev}^{+} \mathrm{BiI}_{4}$.

Thermal behavior of obtained IP was investigated by differential thermal analysis that would show the thermal stability and the character of the decomposition of the complex. The thermolysis of $\mathrm{Lev}^{+} \mathrm{BiI}_{4}^{-}$IP undergoes three stages that fit a theoretical interpretation. The thermogram is shown in (Fig. 2).

Thermal decomposition starts above $45{ }^{\circ} \mathrm{C}$ and is accompanied by the loss of mass and the discharge of the decomposition products. This is followed by carbonization and combustion of the IP which is shown at the thermogram by an exothermal effect at $120{ }^{\circ} \mathrm{C}$ and a loss of mass. On the next stage (295 $375^{\circ} \mathrm{C}$ ) we can see a loss of mass, but no significant thermal effects. At $375-485{ }^{\circ} \mathrm{C}$ thermal decomposition is accompanied by the loss of mass and this is followed by carbonization and combustion of the IP which is shown at the thermogram by exothermal effects at $425,475^{\circ} \mathrm{C}$.

\section{IR Spectroscopy}

In this work, the vibration spectra analysis was carried out by using infrared spectroscopy in the range $400-4000 \mathrm{~cm}^{-1}$. The obtained infrared spectra of the ion-pair of $\mathrm{Lev}^{+} \mathrm{BiI}_{4}{ }^{-}$are shown in Fig. 3, and the infrared band assignments are given in Table 1. These assignments are based on the comparison of the spectra of the formed ion pair and with the spectra of the free reactants (Table 1).

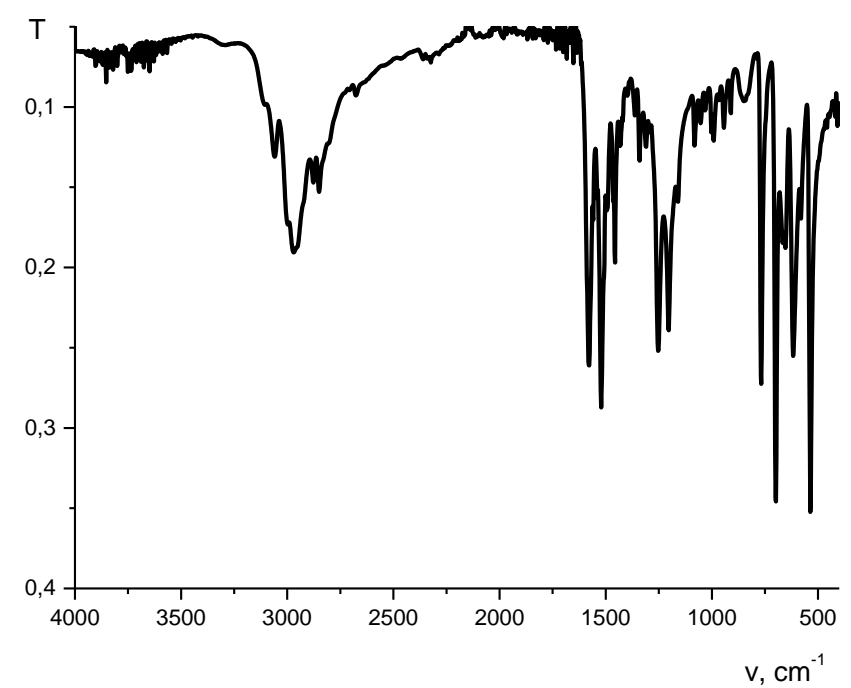

Figure 3. IR spectra of ion pair $\mathrm{Lev}^{+} \mathrm{BiI}_{4}^{-}$. 
Table 1. Observed bands of levamisole, $\mathrm{BiI}_{4}{ }^{-}$and $\mathrm{IP} \mathrm{Lev}^{+} \mathrm{BiI}_{4}{ }^{-}$.

\begin{tabular}{|c|c|c|c|c|c|}
\hline $\begin{array}{l}\text { Wave number } \\
\mathrm{cm}^{-1}\end{array}$ & Assignment & $\begin{array}{l}\text { Wave number } \\
\qquad \mathrm{cm}^{-1}\end{array}$ & Assignment & $\begin{array}{l}\text { Wave number } \\
\text { cm }^{-1}\end{array}$ & Assignment \\
\hline \multicolumn{2}{|l|}{$\mathrm{BiI}_{4}^{-}$} & \multicolumn{2}{|c|}{$\mathrm{Lev}^{+} \mathrm{BiI}_{4}^{-}$} & \multicolumn{2}{|c|}{ Levamisole } \\
\hline 470 & 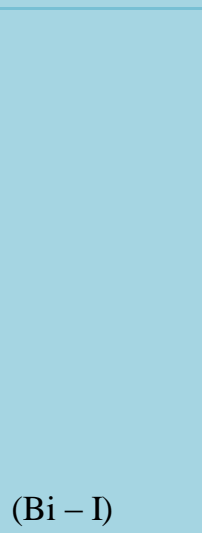 & $\begin{array}{c}1577 \\
1518 \\
1450 \\
1250 \\
1082 \\
770 \\
612 \\
530\end{array}$ & $\begin{array}{l}v(\mathrm{CH}) \\
v(\mathrm{CH}) \\
v(\mathrm{C}-\mathrm{N}) \\
v(\mathrm{C}=\mathrm{C}) v(\mathrm{Ar}) \\
v(\mathrm{CH}) \\
v(\mathrm{CH})_{\text {tiof }} \\
v(\mathrm{CH})_{\text {tiof }} \\
v(\mathrm{CH})_{\text {tiof }} \\
(\mathrm{Bi}-\mathrm{I})\end{array}$ & $\begin{array}{l}3430 \\
3099 \\
3056 \\
2950 \\
1583 \\
1525 \\
1496 \\
1445 \\
1345 \\
1050 \\
737 \\
703\end{array}$ & $\begin{array}{l}v(\mathrm{~N}-\mathrm{H}) \\
v(\mathrm{C}-\mathrm{H}) \\
v(\mathrm{C}-\mathrm{H}) \\
v(\mathrm{C}-\mathrm{H}) \\
\text { Ar.ring } \\
\text { Ar.ring } \\
v(\mathrm{C}-\mathrm{N}) \\
v_{\text {def. }}(\mathrm{C}-\mathrm{H}) \\
v(\mathrm{C}-\mathrm{N}) \\
v(\mathrm{C}-\mathrm{H})_{\text {tiof }} \\
v(\mathrm{C}-\mathrm{H})_{\text {tiof }} \\
v(\mathrm{C}-\mathrm{H})_{\text {tiof }}\end{array}$ \\
\hline
\end{tabular}

\section{Electrochemical behavior of sensor}

The present work exhibits new membrane sensors, $\mathrm{Lev}^{+} \mathrm{SbI}_{4}^{-}$and $\mathrm{Lev}^{+} \mathrm{BiI}_{4}^{-}$, in which $\mathrm{PVC}$ was used as a polymeric matrix. The prepared sensor exhibits good selectivity with respect to related substances, additives in dosage forms and metalions. The conventional design is prepared, characterized and compared according to IUPAC recommendations.

\section{Electrochemical characterization}

Generally, the sensitivity, selectivity, working range, and stability of an ion-selective electrode depend not only on nature of the IP, but are also strongly influenced by the nature and amount of the plasticizer and additives.

To assess the effect of the plasticizer nature, uniform membranes were prepared with DBP, DOP, DBS, DNP, DEP and TCP. It was established that the best plasticizer for membranes based on IAs $\mathrm{Lev}^{+} \mathrm{BiI}_{4}^{-}$and $\mathrm{Lev}^{+} \mathrm{SbI}_{4}^{-}$is $\mathrm{TCP}$ with electrode function slope 52.8 and $54.6 \mathrm{mV} / \mathrm{pC}$ and detection limit $7.9 \times 10^{-5} \mathrm{M}$ and $2.5 \times 10^{-6} \mathrm{M}$ respectively (Table 2). On the fig. 4 there is graphical dependence of the potential of ion-selective electrode on IAs $\mathrm{Lev}^{+} \mathrm{BiI}_{4}{ }^{-}$from amount of plasticizer TCP.

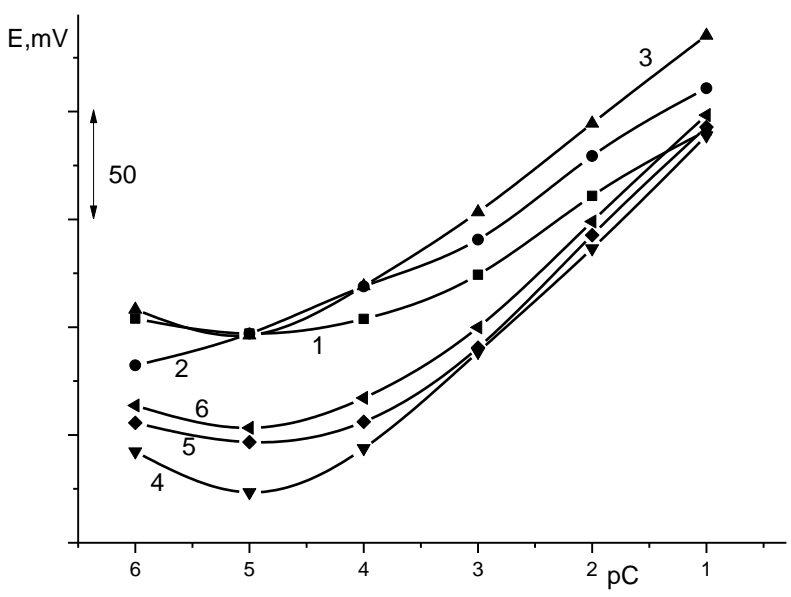

Figure 4. Graphical dependence of the ion-selective electrode potential on the Levamisole $\mathrm{BiI}_{4}{ }^{-}(5 \% \mathrm{EAS})$ concentration $\mathrm{E}=\mathrm{f}(\mathrm{pC})$. TCP content: 1-50\%; 2-55\%; 3-60\%; 4-65\%; 5-70\%; 6-75\%.

\section{Response time}

The time was measured that is necessary for the potential of the membrane electrode to reach the value within $\pm 1 \mathrm{mV}$ of the final equilibrium value after immersing the electrode in the solution of levamisole with 10-fold difference in concentration. The sensors showed rapid response within 15 seconds for drug concentration $\geq 1 \times 10^{-3} \mathrm{M}$ and 25 seconds for $1 \times 10^{-5} \mathrm{M}$. 
Table 2. Response characteristics of PVC levamisole membrane electrode system.

\begin{tabular}{|c|c|c|}
\hline Parameter & $\mathbf{L e v}^{+} \mathbf{S b I}_{\mathbf{4}}^{-}$ & $\mathbf{L e v}^{+} \mathbf{B i I}_{\mathbf{4}}^{-}$ \\
\hline Slope $\mathbf{~ m V / d e c a d e ~}$ & 54.6 & 52.8 \\
\hline Lower linear of range $(\mathbf{M})$ & $7.9 \times 10^{-6}$ & $8.9 \times 10^{-3}$ \\
\hline Lower limit of detection $(\mathbf{M})$ & $2.5 \times 10^{-6}$ & $7.9 \times 10^{-5}$ \\
\hline Response time for $\mathbf{1 0}^{-3} \mathbf{M}(\mathbf{s})$ & 15 & 15 \\
\hline Life span (week) & 4 & 4 \\
\hline Working pH range & $2.8-6.3$ & $2.8-5.8$ \\
\hline
\end{tabular}

The lifetime of the sensors were examined by repeated calibration every 2 days. There was no noticeable deterioration in the sensor performance in terms of detection limit, calibration curve slope and response time over a period of 30 days.

Table 4. Effect of time on response characteristics of PVC levamisole membrane electrode system.

\begin{tabular}{|c|c|c|c|c|}
\hline \multirow[t]{6}{*}{ Lev-BiI ${ }_{4}^{-}$} & Day & $\begin{array}{c}\text { Slope } \\
\text { mV/decade }\end{array}$ & Linear range (mol/l) & $\begin{array}{l}\text { Lower limit of detection } \\
\qquad(\mathrm{mol} / \mathrm{l})\end{array}$ \\
\hline & 2 & 3 & 4 & 5 \\
\hline & 10 & 53,5 & $1 \cdot 10^{-1}-7,2 \cdot 10^{-5}$ & $6,9 \cdot 10^{-5}$ \\
\hline & 20 & 50,3 & $1 \cdot 10^{-1}-7,9 \cdot 10^{-4}$ & $7,2 \cdot 10^{-5}$ \\
\hline & 60 & 48,7 & $1 \cdot 10^{-1}-3,6 \cdot 10^{-5}$ & $2,2 \cdot 10^{-5}$ \\
\hline & 90 & 44,9 & $1 \cdot 10^{-1}-3,2 \cdot 10^{-5}$ & $1,6 \cdot 10^{-5}$ \\
\hline
\end{tabular}

\section{Effect of the medium acidity}

The $\mathrm{pH}$ effect of the tested solution on the electrochemical behavior of the sensor was studied under a constant concentration of levamisole hydrochloride and varying the content of the hydrogen ions in the $\mathrm{pH}$ range of 2.0-7.5 which was adjusted with an $\mathrm{HCl}$ or $\mathrm{NaOH}$ solution. The results

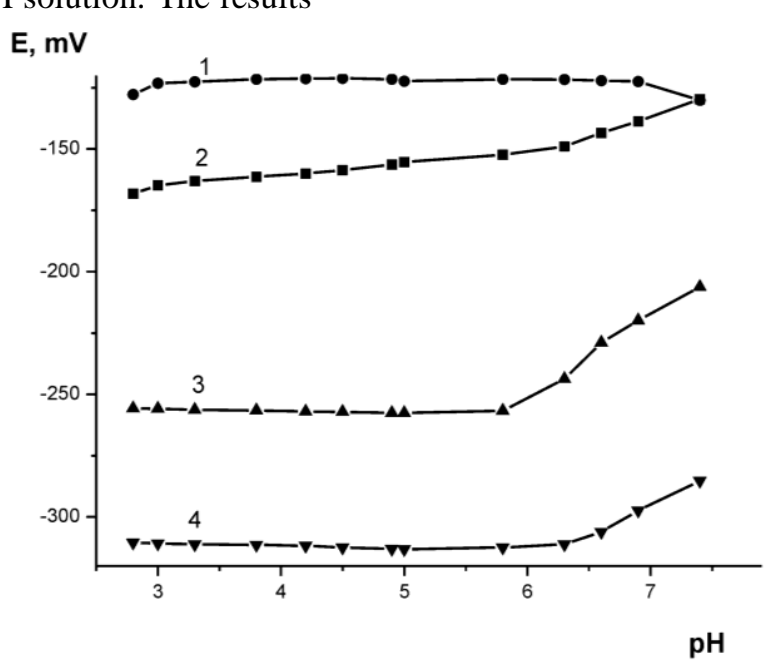

Figure 5. Effect of $\mathrm{pH}$ of test solution on the potential response of the proposed sensors: $\mathrm{Lev}^{+} \mathrm{SbI}_{4}{ }^{-}$:

are illustrated in Fig. 5. The potentials keep constant in the $\mathrm{pH}$ range of $2.8-6.0$. The observed potential drift at lower $\mathrm{pH}$ values may be attributed to the membrane response to $\mathrm{H}^{+}$and at higher $\mathrm{pH}$ values $(\mathrm{pH}>9)$ could be due to the formation of levamisole in ionic form $(\mathrm{pKa}=9.5)$ 
Table 3. Potentiometric selectivity coefficients $\left(K_{L e V}^{p o t}{ }_{{ }^{\prime} I^{+}}\right)$for some common cation with levamisole -PVC membrane sensors.

\begin{tabular}{|c|c|c|}
\hline Interferant, $\mathrm{I}^{+}$ & \multicolumn{2}{|c|}{$-\lg \left(\mathrm{K}_{\mathrm{Lev}}^{\mathrm{pot}}{ }^{+}{ }_{\mathrm{I}}^{+}{ }^{+}\right.$} \\
& $\mathrm{Lev}^{+} \mathrm{SbI}_{4}^{-}$ & $\mathrm{Lev}^{+} \mathrm{BiI}_{4}{ }^{-}$ \\
\hline $\mathrm{NH}_{4}^{+}$ & $>4$ & $>4$ \\
\hline $\mathrm{Cu}^{2+}$ & 2.6 & 3.8 \\
\hline $\mathrm{K}^{+}$ & $>4$ & $>4$ \\
\hline $\mathrm{Na}^{+}$ & $>4$ & $>4$ \\
\hline $\mathrm{Co}^{2+}$ & $>4$ & $>4$ \\
\hline $\mathrm{Ba}^{2+}$ & $>4$ & $>4$ \\
\hline $\mathrm{Ca}^{2+}$ & $>4$ & $>4$ \\
\hline $\mathrm{Mg}^{2+}$ & $>4$ & 3.9 \\
\hline 2,3,5-Triphenyltetrazolium chloride & 0.9 & 2.3 \\
\hline N-cetylpyridinium chloride & $>4$ & $>4$ \\
\hline Tetramethylammonium bromide & $>4$ & $>4$ \\
\hline Cetyltrimethylammonium bromide & $>4$ & $>4$ \\
\hline Tetrabutylammonium iodide & $>4$ & $>4$ \\
\hline Benzyltrimethylammonium chloride & $>4$ & $>4$ \\
\hline Benzalkonium chloride & 2.3 & 3.3 \\
\hline
\end{tabular}

The potentiometric selectivity coefficient of the levamisole based sensors depends on the selectivity of the ion-exchange process at the membrane-sample interference, the mobility of the respective ions in the membrane. The free energy transfer of the Lev ion between the aqueous and the organic phase could also control the selectivity of the proposed sensor. Obtained results are summarized in Table 3. No interference from ions such as $\mathrm{NH}_{4}^{+}, \mathrm{K}^{+}, \mathrm{Na}^{+}, \mathrm{Co}^{2+}$, $\mathrm{Ba}^{2+}, \mathrm{Ca}^{2+}, \mathrm{Mg}^{2+}$ etc. was recorded. The proposed sensors exhibited a high selectivity towards levamisole with respect to the test ion.

\section{Analytical application}

Levamisole in various drugs formulation was determined by direct potentiometric measurements, potentiometric titration using these sensors. The potentials measured by those sensors were recorded and compared with the calibration graph. The proposed membrane sensor based on ion-pair of levamisole $\mathrm{SbI}_{4}^{-}\left(\mathrm{Lev}^{+} \mathrm{BiI}_{4}{ }^{-}\right)$was found to work well under laboratory conditions. It was applied for the determination of levamisole in pharmaceutical forms (Table 4). Comparing the dispersion of the direct potentiometric and potentiometric titration methods of the levamisole determination using $F$-test, one can see that the techniques are uniformly correct. The comparison of the set of averages Student's test shows that the uniform correctness of obtained data is observed for both proposed sensors. Calculated value of $F$-test $\left(F^{*}\right)$ and Student's test $\left(t^{*}\right)$ are significantly lower that the respective table data $\left(F^{*}\right.$ $\left.<F_{\text {tabl. }}=5.05, t^{*}<t_{\text {tabl. }}=2.78\right)$.

Table 4. Result of the determination of levamisole $\left(F_{\text {tabl. }}=5.05 ; t_{\text {tabl }}=2.78\right)$.

\begin{tabular}{|c|c|c|c|c|c|c|c|c|c|}
\hline \multirow[t]{2}{*}{ Sample } & \multirow{2}{*}{$\begin{array}{c}\text { Label } \\
\text { amount, } \\
\text { mg }\end{array}$} & \multicolumn{3}{|c|}{ Found by proposed sensor } & \multicolumn{3}{|c|}{$\begin{array}{c}\text { Found by potentiometric } \\
\text { titration }\end{array}$} & \multirow[t]{2}{*}{$F^{*}$} & \multirow[t]{2}{*}{$t^{*}$} \\
\hline & & $\mathrm{mg}$ & $S^{2}$ & $\begin{array}{c}\text { RSD } \\
(\%)\end{array}$ & $\mathrm{mg}$ & $S^{2}$ & $\begin{array}{c}\text { RSD } \\
(\%)\end{array}$ & & \\
\hline Decaris* & 150 & $150.2 \pm 1.08$ & 0.75 & 0.58 & $151.1 \pm 1.24$ & 0.99 & 0.66 & 1.32 & 1.18 \\
\hline Decaris* & 50 & $50.3 \pm 0.49$ & 0.16 & 0.79 & $50.3 \pm 0.49$ & 0.16 & 0.79 & 1.00 & 0 \\
\hline $\begin{array}{l}\text { Levamisole- } \\
\text { Zdorovye, }\end{array}$ & 150 & $151.1 \pm 1.24$ & 0.99 & 0.66 & $151.4 \pm 1.39$ & 1.14 & 0.71 & 1.15 & 0.34 \\
\hline Urine & 59 & $58.0 \pm 1.1$ & 0.74 & 1.46 & $57.9 \pm 1.1$ & 0.8 & 1.51 & 1.08 & 0.14 \\
\hline
\end{tabular}

* - Richter Gedeon Ltd, Hungary; ** - Kharkiv Ukraine 


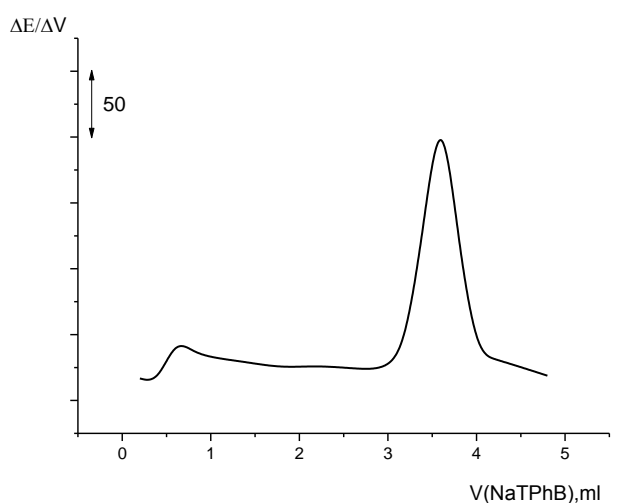

a)

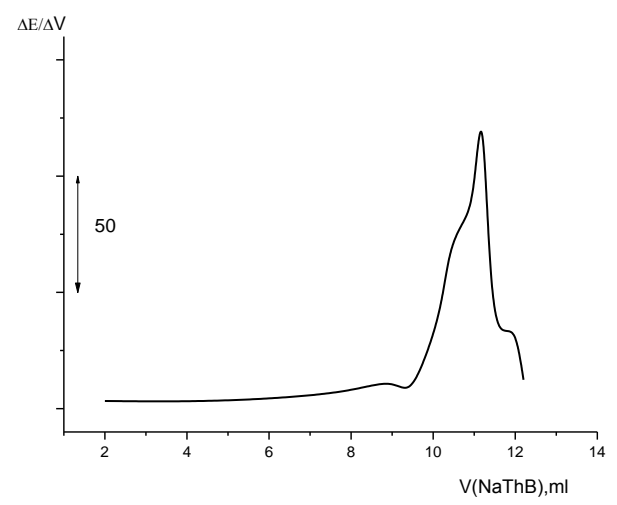

b)

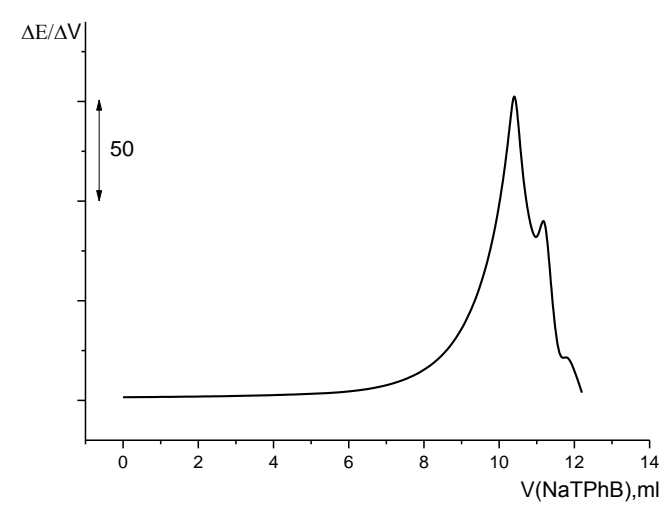

c)

Figure 6. Potentiometric titration curve in the pharmaceutical forms (a - Decaris, Richter Gedeon Ltd,50 mg/tablet; b - Decaris, Richter Gedeon Ltd, 150 mg/tablet; c - Levamisole-Zdorovye, Kharkiv Ukraina, 150 $\mathrm{mg} /$ tablet.

The sensor was also successfully applied as an indicator electrode in the potentiometric titration of levamisole with tetraphenylborate (NaTPhB) (Fig. 6). The $0.01 \mathrm{M}$ solution of sodium $\mathrm{NaTPhB}$ was used as titrant. As the solubility product of the formed precipitate is sufficiently low, the concentration of levamisole in the solution near the equivalency point decreases sharply, which is manifested in a potential jump at the titrant curve.

The recovery results are shown in Table 5. Three replicate determinations at different concentration levels were carried out using the three electrodes to test the precision of the method. The standard deviations were found to be $1.0-1.5$, indicating reasonable repeatability and reproducibility of the selected method. The precision of the method was calculated in terms of (intra-day and inter-day). The $\%$ RSD values of intra-day and inter-day studies for the repeated determination were less than $2 \%$ indicating good precision.

Table 5. Validation of the proposed method for the determination of Lev in pure form.

\begin{tabular}{|c|c|c|c|c|c|c|}
\hline \multirow[t]{2}{*}{ Conc. (mol/l) } & \multicolumn{3}{|c|}{$\mathrm{Lev}^{+} \mathrm{BiI}_{4}^{-}$} & \multicolumn{3}{|c|}{$\mathrm{Lev}^{+} \mathrm{SbI}_{4}^{-}$} \\
\hline & Recovery \% & $\operatorname{RSD} \% *$ & Error $\% * *$ & Recovery $\%$ & $\operatorname{RSD} \% *$ & Error $\% * *$ \\
\hline \multicolumn{7}{|c|}{ Intraday precision } \\
\hline $1 \cdot 10^{-6}$ & 99.02 & 0.65 & 0.29 & 99.00 & 0.72 & 0.32 \\
\hline $1 \cdot 10^{-5}$ & 99.12 & 0.48 & 0.21 & 99.05 & 0.55 & 0.25 \\
\hline $1 \cdot 10^{-4}$ & 99.56 & 0.38 & 0.17 & 99.56 & 0.45 & 0.20 \\
\hline \multicolumn{7}{|c|}{ Interday precision } \\
\hline $1 \cdot 10^{-6}$ & 98.04 & 0.69 & 0.31 & 99.03 & 0.65 & 0.29 \\
\hline $1 \cdot 10^{-5}$ & 99.12 & 0.54 & 0.24 & 99.18 & 0.58 & 0.26 \\
\hline $1 \cdot 10^{-4}$ & 99.86 & 0.42 & 0.19 & 99.22 & 0.49 & 0.22 \\
\hline
\end{tabular}

$* \% \mathrm{RSD}=(\mathrm{S} . \mathrm{D} / \mathrm{Mean}) 100$

$* * \%$ Error $=\% \operatorname{RSD} / \sqrt{ } \mathrm{n}$ 


\section{Conclusion}

New levamisole electrode with polyvinylchloride membrane was developed that contain ion-pairs of levamisole with inorganic counter-ions $\mathrm{SbI}_{4}^{-}$or $\mathrm{BiI}_{4}^{-}$as electrode-active substances. Thermal behavior of obtained IP was investigated by differential thermal analysis that would show the thermal stability and the character of the decomposition of the complex. The thermolysis of $\mathrm{Lev}^{+} \mathrm{BiI}_{4}^{-} \mathrm{IP}$ undergoes three stages that fit a theoretical interpretation. The proposed electrodes exhibit long lifetime, good stability, sensitivity, precision, accuracy and selectivity. They are lowcost, easy to prepare and to use.

On the basis of experimental results we have shown the successful applicability of the new membrane electrodes based on the ion-pairs of $\mathrm{Lev}^{+}$ with $\mathrm{SbI}_{4}^{-}\left(\mathrm{BiI}_{4}^{-}\right)$for the determination of levamisole in pharmaceutical forms and urine. The comparison of the set of averages Student's test shows that the uniform correctness of obtained data is observed for both proposed sensors.

\section{References}

1- L. Tong, L. Ding, Y. Li, Zh. Wang, J. Wang, Y. Liu , L. Yang, A. Wen, A sensitive LCMS/MS method for determination of levamisole in human plasma: Application to pharmacokinetic study. Journal of Chromatography, 2011, B 879, 299-303.

2- R. Woestenborghs, L. Michielsen, J. Heykants , Determination of levamisole in plasma and animal tissues by gas chromatography with thermionic specific detection. J. Chromatogr., 1981, 224, 25.

3- E. Kouassi, G. Caille, L. Lery, L. Lariviere, M. Vezina, Novel assay and pharmacokinetics of levamisole and p-hydroxylevamisole in human plasma and urine. Biopharm. Drug Dispos., 1986, 7, 71-89.

4- M. Alvinerie, P. Galtier, G. Escoular, Ion-pair high performance liquid chromatographic assay of levamisole in biological fluids. J. Chromatogr. 1981, 223, 445-448.

5- S. De Baere, M. Cherlet, S. Croubels, K. Baert, P. Backer, De Liquid chromatographic determination of levamisole in animal plasma: ultraviolet versus tandem mass spectrometric detection. Analytica Chimica Acta 2003, 483, 215-224.

6- H. El-Kholy, B.W. Kemppainen, Liquid chromatographic method with ultraviolet absorbance detection for measurement of levamisole in chicken tissues, eggs and plasma. J. Chromatogr. B, 2003, 796, 371-377.

7- T.F. Vandamme, M. Demoustier, B. Rollmann, Quantitation of levamisole in plasma using high performance liquid chromatography. Eur J Drug Metab Pharmacokinet. 1995, 20, 145-149.

8- A. Holbrook, B. Scales, Polarographic determination of tetramisole hydrochloride in extracts of animal tissue. Anal. Biochem., 1967, $18,46-53$.

9- J. M. Calatayud, C. Falco, Determination of levamisole hydrochloride with $\mathrm{HgI}^{2-}$ by a turbidimetric method and flow-injection analysis. Talanta, 1986, 33, 685-687.

10-S. Sadeghi, F. Fathi, J. Abbasifar, Potentiometric sensing of levamisole hydrochloride based on molecularly imprinted polymer. Sensors and Actuators B, 2007, 122, 158.

11-N. Zubenia, Zh. Kormosh, D. Semenyshyn, V. Kochubei, S. Korolchuk, T. Savchuk, Desing and application of a levamisole-selective membrane sensor. Anal. Bioanal. Electrochem., 2016, 8, 466-477.

12-Zh. Kormosh, O. Matviychuk, Potentiometric determination of mefenamic acid in pharmaceutical formulation by membrane sensor based on ion-pair with basic dye. Chin. Chem. Lett., 2013, 24, 315317.

13-Zh. Kormosh., I. Hunka, Ya. Bazel, Potentiometric determination of diclofenac in pharmaceutical formulation by membrane electrode based on ion associate with base dye. Chin. Chem. Lett. , 2007, 18, 103-106.

14-Zh. Kormosh., T. Savchuk, New potentiometric sensor for the determination of iodine species. Mater. Sci. Eng. C 32, 2012, 2286-2291.

15-Zh. Kormosh., T. Savchuk, S. Korolchuk, Ya. Bazel, Design and application of a triiodide-selective membrane electrode. Electroanalysis 2011, 23, 2144-2147.

16-Zh. Kormosh., I. Hunka I., Ya. Bazel, Matviychuk O. Potentiometric determination of ketoprofen and piroxicam at a new PVC electrode based on ion associates of Rhodamine 6G. Mater. Sci. Eng. C 30, 2010, 997-1002.

17-Zh. Kormosh., L. Hunka, Ya.Bazel, Potentiometric sensor for the indomethacin determination. Mater. Sci. Eng. C, 2009, 29, 1018-1022.

18-Zh. Kormosh., I. Hunka, Ya. Bazel, A potentiometric sensor for the determination of diclofenac. J. of Anal. Chem., 2009, 64, 853-858.

19-J. Lenik, Preparation and study of a naproxen ion-selective electrode. Mater. Sci. Eng. C, 2013, 33, 311-316. 